\title{
Performing gendered distinctions: Young women painting illicit street art and graffiti in Helsinki
}

Malin Franbserg

\begin{abstract}
:
This article studies illicit street art and graffiti subculture among women in Helsinki, taking feminist subcultural theory into account. In previous studies of illicit street art and graffiti, women's participation has been overlooked partly due to lack of data and through the tendency of seeing them as one unified marginalised group. Through ethnographic fieldwork, using edgework as the methodological approach, and interviews with eight women painting street art and graffiti in Helsinki, this article presents a critical perspective on how these women negotiate their positions in the subcultures from different positions. Particularly, it examines the performed gendered distinctions between street art and graffiti, and the negotiations of subcultural subjectivity.
\end{abstract}

Keywords: graffiti, street art, gender, subculture, distinction

\section{Introduction}

The canon of study on graffiti and street art has moved from being simply descriptive (Castleman 1982; Chalfant and Prigoff 1987) to framing a deeper analysis of subcultural youth resisting control and identity constructions (Ferrell 1996; Macdonald 2002; Snyder 2009). Moreover, the rises of sanctioned/illicit street art have expanded the understanding of contemporary graffiti, contesting both its communities, as well its boundaries and means, and therefore sometimes referred as 'postgraffiti' (Waclawek 2011). The term 'post' “suggests a chronological progression and distancing from the established visual tradition and principles of signature graffiti” (Waclawek 2011, 30). On the visual basis throughout the literacy graffiti and street art tends to be mixed, challenging both the 
definitions of the subject matter studied and, therefore often the analysis of the empirical findings. It is not always clear among graffiti and street art scholars what they exactly are examining. While the definitions of the terms seems to be one subject matter in the scholarly literature of graffiti and street art (Ross 2016), there are theoretical approaches that aims to look at graffiti and street art as an expression of a gendered identity within youth subculture (Lombard 2013; Macdonald 2002; Monto, Machalek and Anderson 2012; Pabón 2016). Particularly, graffiti has been recognised as a 'resource which young men can use to construct and validate youthful masculine identity' (Macdonald 2016, 183). Especially, the competitive nature of graffiti as a means of recognition on the streets in the name of the 'fame' have often been presented as sole reason for participating in graffiti writing (Macdonald 2002; Snyder 2009; Ferrell 1996). This takes the masculine values for granted, as other motivations for participating in graffiti subcultures are set aside. Yet, in the case of street art there are less scholarly studies on its 'masculine nature', merely it has been noted to be disseminated also by a great number of women (Waclawek 2011, 30; Ganz 2007). Whether graffiti and street art should be studied as separated or mediated phenomena, the groups of women participating within these subcultures do make an interesting intersection amongst the prejudgments of who is traditionally cultivating the street cultures.

This study is part of a larger research on illicit street art and graffiti in Helsinki, which has been conducted through multiple ethnographic methods since 2011. The ethnographic fieldwork has slowly developed from observing and participating in a male-dominated scene to recognising a growing female scene in the city of Helsinki (Fransberg 2013; 2014). Through ethnographic methods, this paper studies young female graffiti and street artists in Helsinki and their experiences of graffiti writing and street art as subordinated members within a male-dominated field of arts. Particularly, it examines the performed gendered distinctions between street art and graffiti, and the negotiations of subjectivity in spheres that are typically cultivated by males. The notion of 'performativity’ is here drawn on Judith Butler’s (1991) concept. Besides the meager studies on 
gender within graffiti and street art, the focus on the female subjectivity within the often male dominated discourses within subcultures research, is also an attempt to move away from the 'subculture vs. post-subculture' debate and toward current understandings of what shapes the 'subcultural subject' (Kempson 2016, 140). The understanding of subjectivity in relation to subculture in feminist research is often done by presuming that particular social groups are either oppressed within the subcultures they interact with, and therefore pushed into the peripheries of such spaces, or that they cultivate separate spaces in order to avoid such oppression (Kempson 2016, 140 - 141). This perspective is easily understood when looking at graffiti, where women are seen as exceptions in a male-centered sphere, versus street art, where women are forming an own space in order to avoid the sexism that is typically presented in graffiti subculture. However, there are further accounts that may present structural inequality within these subcultures themselves, pointing out that these fields are usually presented as essentially 'male' spaces through the lens of particular knowledge paradigms that marginalises alternative experiences (Kempson 2016; Halberstam 2005). For example, what are the stylistic inequalities between the women painting graffiti and street art, and how is this negotiated? There is a problematic notion in studying graffiti and street art painting women as one united group, particularly when the two art forms often represent different rebellions and resistance, both to each other and to the world outside.

\section{Women in studies on graffiti and street art}

Graffiti originated among the youth in ethnically diverse areas of New York, Philadelphia and Chicago late 1960s when young people started writing their names (tags) in the city space and on the subways. In its early days, 'tags' appeared as a combination of a writers' real name and the numerical street number, thus others knew whether the writer was female or male (Austin 2001; 
Waclawek 2011, 14). Male dominance within the subculture was presented as the norm, even though also women had painted graffiti ever since the start of the movement with figures such as Barbara62, Eva62 and Lady Pink (Austin 2001; Macdonald 2002). Graffiti as a name writing culture spread to Europe and Finland which this study concerns through documentaries such as Style Wars and Wild Style in the mid-1980s. In Finland, girls’ participation in graffiti subculture has been noted since 1991, as we see with the ‘bombing girls’ by Jaana Lähteenmaa’s (1991) scholarly study on hip-hop youth culture in Helsinki, as well in popular literature 'Helsinki graffiti' which documents few girls bombing trams along with the boys (Isomursu and Jääskeläinen 1998). Piritta Malinen (2011, 96), although she found no women to interview in her pedagogical Phddissertation on graffiti, discusses the rarity of female graffiti writing as a reason for structural male dominance, thus girls in the movement need a particular encourage and circumstance in order to participate in graffiti painting. A recent survey of legal graffiti and street art painters at an authorised wall in Helsinki concludes that 5\% $(\mathrm{N}=186)$ are women $($ Helin 2014, 77).

Even though women are present as a minority in many studies of graffiti, scholars have focused little on gender inequalities, with only a few graffiti and street art studies that critically analyse women’s participation as marginalised and subordinated agents (Macdonald 2002; 2016; Pabón 2013). Nancy Macdonald (2002) analyses the construction of masculine identities through a search for respect and fame in graffiti subculture. Her London- and New York-based ethnography is the most important analysis for 'gender regimes’ (see McRobbie 2009) in graffiti subcultures, though only three women were interviewed in the study. Macdonald $(2016,233)$ critically points out that a female writers' contribution in the subculture is often minimised by focusing instead on their sexual activities, questioning their dedication and accountability, thus they are not seen 'authentic' enough. Kara-Jane Lombard (2013) continues Macdonald’s thesis, adding that graffiti masculinity embodies the coloniser's ideals of masculinity that is dangerous, aggressive and takes risks; hence as Macdonald, she focuses on the expressions of male identity. Jessica Pabón (2013; 
2016) is one of the only scholars that exceptionally focus on women's participation in graffiti. She notes the increasing number of women, both young and adults, influenced by the internet to participate in graffiti subculture. Digital/social media and internet use have established a visible presence for women and a space for female solidarity in graffiti subculture where those of the minority genders can share common experiences. Moreover, the digital and social media has increased the ways of being seen, as women among street art and graffiti do not present a unified gender but diverse identities.

Gender has been studied only a little when it comes to the case of illicit street art, although certain distinctions can be found on the street arts' 'gender' in relation to graffiti. Graffiti writing is often presented as more subcultural, and is predominantly (male) subcultural discourse, as the street art have been understood as more mainstream and even 'female friendly' (Ganz 2006; Macdonald 2016; Pabon 2016). Nicholas Ganz $(2006,11)$ writes ‘In some ways the street art movement seems more open to and tolerant of women. It attracts few or none of the 'male obstacles' you associate with the graffiti movement, and women tend to be seen in a positive light and supported.' Ganz book named Graffiti Woman presents more than 100 artists, most of them painting actually street art and only a few graffiti. Street art does not follow the orthodox rules of graffiti: it is not restricted to letters; it uses techniques that are not traditionally used in graffiti painting, such as stencils, stickers, lamination or any kind of installation created in urban spaces without permission. Because of its communicative intension with its viewers and less cryptic message than signature graffiti, it is typically read as more social, less aggressive and therefore more 'feminine'. For example, guerrilla knit -pieces (yarn bombing) are conventionally presented as a female practice brought into a conversation with a traditionally male movement (Waclawek 2011, 72). Pabón (2016, 119) summarises the overly simplified assumptions on that women are more likely to participate in street art than in graffiti in the following ways; the juridical designation of street art as "art" versus graffiti as “vandalism” (women less likely to participate in criminal behavior), the preparation of street art 
in the private domain (women inclined to be more comfortable in the safety of private sphere) and the lack of interest in 'making masculinity' (women not having desire to exercise masculine behaviors).

Despite the representative differences between street art and graffiti, some scholars contest the two have been 'arbitrarily separated' through governmentality (Leslie and Hunt 2013; McAuliffe 2012) and by urban policy language 'as it reflects the commodification of street culture and the selective appropriation of graffiti into mainstream art systems’ (Georgiou 2013, 160). However, the potential danger in dividing these two art forms has its risks'; one may study "good” street art, vs. "bad” graffiti (Ross, et. al. 2017, 416), a typical discourse also in public domains. Yet, it is the common features shared by street art and graffiti that makes it interesting to analyse young women's participation within these two discourses, not as a unified group but as actors that implement the distinction between street art and graffiti. Both art forms tend to be unauthorised, the illegality being a driving force for its practioners, and both are impelled alter the public space. Thus, they both tend to question the notion of public space and especially, who is cultivating the streets. Further, in contrast to other subcultural groupings, graffiti and street art are largely disembodied, as the physical person behind the art remains absent from the present (Hannerz 2017). The performative body is mostly invisible, but it is still likely to be drawn on normative notions of the male body, both inside the subcultures, as outside the subcultures.

\section{Researcher positionality: the field, edgework and methods}

As part of a larger research in graffiti and street art subculture in Helsinki, this article presents the first foray to the women's field in the city. It further presents a specific shift from women being isolated subjects in graffiti and street art scenes to the radical change of a growing 
number of female painters' in Helsinki. The visibility of women in graffiti and street art was practically non-existent for outsiders until the first authorised street art walls appeared after the end of the municipal led zero tolerance against graffiti and street art in $2008^{1}$. This is not to say that there were no women in the field before this, but their visibility was largely disembodied also inside the subculture. As Hannerz $(2017,374)$ notes, the disembodiment and the absence of the performative body have been deepened as an effect of zero tolerance, and as a consequence most artist were largely unware of each other. A further suggestion here is that its effect deepened the male dominance, as women were widely isolated from each other as a result of the subcultures' 'male' assumption. The legal walls enabled the visibility and meeting of diverse bodies that had remained invisible during zero tolerance and $\mathrm{Katri}^{2}$ was one of the first graffiti writing women I ever met in Helsinki at one of the legal walls. She was a typical street bomber with her rude and fearless attitude. Before her, I had been largely unware of other women in the field, even if graffiti subculture has maintained a central role in my sense of identity, tastes and social life since the age of 14. After Katri, I have gradually met more than 30 young women painting street art and/or graffiti in the ethnographic terrain in Helsinki, mostly by drifting around among graffiti and street artists but also through municipal led youth work ${ }^{3}$. This allowed me to explore the somewhat different distinctions between the 'underground' and 'legal' or semi-legal scenes in Helsinki.

\footnotetext{
${ }^{1}$ Helsinki experienced significant change in its policy against graffiti and street art, shifting from a strict zero tolerance policy (1998-2008) to celebrating urban arts, which are now consumed through different institutions and municipal-led youth work. The "Stop graffiti" -project $(1998$ - 2008) was led by the municipal Urban Environment Division, the state owned train company 'VR' and private security companies, such as 'Finnish Protection Service' (FPS). Similar to other Nordic countries, the zero tolerance policy was built on the belief of that legal graffiti and street art will work as a gateway to illegal art and vandalism, and eventually more serious crime among the youth (Høigård 2007; Kimwall 2014; Koskela 2009). Since the policy change in 2008 the Youth Department of Helsinki has actively developed youth work focusing on graffiti and street art through authorised walls, workshops and online-work. Moreover, the growing number of graffiti and street art exhibitions in the city's galleries have somewhat confirmed the popularisation and commodification of the art forms. The assumed intersections of the subcultural subject has therefore changed from being a troubled white working-class youth male to new representations, such as the seniors' 'K65-crew', or female-only projects like 'Mimmit peinttaa'.

${ }^{2}$ All names of the participants are anonymised.

${ }^{3}$ In autumn 2013, I was teaching a graffiti workshop for young women, authorised by the municipal Youth Department. Together with a group of young women in age $17-29$, we met weekly during three months at
} 
From these communities, I eventually approached eight individuals to participate in-depth interviews, on the basis that they all painted illicitly and thus were fostering a more 'subcultural' identity. The sample is mixed consisting of both street artists and graffiti writers who were found from the informal networks maintained by traditional field research and the youth work. The empirical data in this text draws mainly from these ethnographic interviews and field notes that I conducted with the eight women over six months, from June to December 2014. During the field observation, participants Satu, Minna, Leena, Laura, Katri, Tiina, Emmi and Ines were between 19 - 30 years, most of them between 25 - 29. During the six months period, I taped one in-depth interview with each of the women, ranging from 60 - 150 minutes. The interviews were loosely structured, based on researchers' insights of the field and on information that had been collected through ethnographic field notes from these and other study participants.

The group of women studied here, are white, heterosexual and working class, although they were developing a certain cultural capital through their labour market participation and education. In a similar manner to Tarja Tolonen’s (2013) study of Finnish middle-class ‘Theatre Girls’, these women were artistic and performing certain middle-class values in their style and appearance. Moreover, during the interview and observation period, six of the women were working or studying in a field that required handicraft and artistic perspective. Their designation as 'working class' stems from their educational background: most of these women had or were completing a degree from vocational school, an alternative to a high school degree that enables youth in Finland to attend university. They were not typically academic; although two of them had been enrolled in a lower university degree and a third woman had completed one. Two of the women had short-term

authorised street art walls, equipped with spray cans fund by the Youth Department. At the walls we would teach each other different painting techniques, 'hung out', share gossips from the scene and discuss the plans for the weekend. During the workshops I noted that only few girls were interested in doing 'traditional' graffiti among the mostly street art -oriented group, something that my boss was even 'worried' about as he urged me to get 'the girls to do more graffiti', something that I noted was difficult to do since they simply did not show interest. 
contract work and non-permanent employment, and one was on maternity leave from a vocational school. Thus, their class was not a fixed; rather it displays their positions as transformations to adulthood. Another indicator of the mix between working-class and middle-class values was that they were able to move, to some extent, elegantly between these domains. For instance, we could attend an exclusive night club, but brought our own beer cans from which we would fill up our glasses under the tables, instead of buying expensive drinks. Some of the women knew how to shoplift expensive shoes or jackets, while many of us dodged fares on the local public transport system. Although many of the women adapted various skills in managing economic deprivation in favour of 'living up to middle-class standards', I must state that not all of the women in this study used typically 'deviant' behaviour to achieve this. They were instead working and studying hard to reach their personal goals in a conventional society.

Ethnographic research has been shown to be an appropriate method for understanding graffiti and street art (Ferrell 1996; Macdonald 2002; Snyder 2009). It enables ‘thick’ descriptions of subcultures and the nuances inside them. The most important outcome in this method is building trust with participants through the researchers' engagement with the field, often through the own immersion into it. In particular, the ethics of ethnography is to ensure the anonymisation of participants, especially because of their sensitive information of criminal acts. I have drawn particularly upon ethnographic fieldwork on the notion of edgework (Lyng 1990). Stephen Lyng (1990) describes edgework as behaviour where one seeks to go voluntarily beyond the 'edge' of safety or the law, demonstrating how an individual can develop ‘self-determination’ and 'confidence'. Ethnographic edgework certainly contributes to studies of illicit graffiti and street art practice. Cultural criminologists (Ferrell and Hamm 1998) affirm edgework as a methodology to understand subcultural membership, as edge and adrenaline are shown to coexist. However, edgework has been criticised as a gendered concept, taking male performance for granted in its theoretical discussion of voluntary risk-taking behaviour (Lois 2003, Gailey 2009, Newmahr 2011). 
Shane Blackman $(2016,72)$ suggests, referring to Jennifer Lois $(2003,181)$, that in order to counter edgework’s gender bias and masculine middle-class preoccupation with leisured risk and being 'emotionally cool', fieldwork politics should understand emotions as something constructive and meaningful. Blackman’s (2016) ‘emotional edgework’ may enhance the understanding of fieldwork, where one both researches and participates in a subculture among friends.

Some research participants became close friends to me and I became emotionally attached to them, which has subsequently affected my interpretation of the data. Moreover, the most difficult task has been to understand the effects of that I initially searched for graffiti writing women, but found out that actually many women refused to be defined as graffiti writers, but as street artists. My prior field research of the male-dominated field of train graffiti writers in Helsinki (2011 2013) has somewhat confirmed my mobility and access to the subcultural scene. Train writers often are positioned as the 'inner circle’ of the graffiti subculture, which might also challenge a feminist position researching women on the periphery. Some of my research participants knew about my subcultural background, the field research among train writers and all knew my role as a teacher in the municipal-led youth workshop. Taking all this into account, the differences in status and power between the researcher and the researched, is a critical claim legitimated by feminist scholars (Madison 2005). Even with 'gender match' with research participants, age, ethnicity and educational background could create substantial barriers. My own role was complicated both through my possession of subcultural knowledge as an 'insider researcher' (Hodkinson 2005, 138 139) and as an academic among marginalised subcultural subjects. I sometimes noted my different subcultural position when research participants would ask for advice on techniques for painting 'hot spots' or trains, which put me in an ethical dilemma as a youth worker but also as a friend, who positions subcultural knowledge. On the other hand, the ability to share subcultural gossip, anecdotes and observations with participants may enhance interview conversations, creating a twoway exchange instead of the usual question-and-answer form (Hodkinson 2005, 139). This offers 
substantial advantages in terms of trust between the research participants and researcher, in particular where the aim is to build feminist accounts.

\section{Gendered distinctions between street art and graffiti}

During the years of field research in Helsinki, I often heard when male graffiti writers encouraged their girlfriends to paint with them: "You can do a character next to my piece" was a typical comment that underpinned the assistive female role in graffiti subculture and its relation to street art. Rarely did I hear a male encourage a female friend to make an entire graffiti piece herself. Characters (fictive figures, animals, popular cartoon, etc.) next to graffiti pieces were positively commented amongst graffiti and street artists in Helsinki, but their function was often shaped as a supportive assemble of the graffiti piece itself, placing the tag name in centrum. Waclawek (2011, 39, 41) argues that street artists have detached the character from the graffiti subculture and eventually developed a distinctive art form, thus "it owes much to the original culture of graffiti writing, which paved the way for the creation of unsanctioned art in the city”. This stance should be critically looked up-on as it takes street art automatically as subordinated to graffiti and underpins the marginalisation of street art and its knowledge production in subculture.

In this study on the visual basis, four of the women were mostly painting street art and four mostly graffiti. The women identified as 'street artist' made different kinds of characters, stencils, posters or stickers, although the main tool for them all was spray paint. Some of them would often paint together with other graffiti writers, as an incorporated part of bigger graffiti murals, others alone on the streets. Street art and graffiti in Helsinki as two distinctive arts' was identified by aesthetical basis, but also throughout the distinctions the women proposed in the interviews, where graffiti was illustrated as fixed and street art something else: 
"I'm more like a street artist because graffiti is graffiti and it's annoying when somebody says that 'oh, that sun on the wall, it's graffiti', that's just so dumb. So maybe I'm like, well street artist is a better word for that. I don't think I'm, well it's hard to name yourself into one style.” - Laura, $25^{4}$

"Maybe I'm more like a street artist because I'm not doing (graffiti) pieces that often. I'm more trying to do a thing that would be more like my own style. But, everyone can put me in any box they want, graffiti or street-art, something between. Both are interesting for me. ”- Ines, 19

Laura and Ines refused to be fully fixed into one of the 'boxes', although both recognised they were 'more like a street artist' and that it was important to picture the differences between the two. The understanding of separate spaces does not prevent from identifying with both arts simultaneously, as subcultures often overlap each other or share common spaces. To pinpoint the differences was a way to mark one’s capacity of subcultural knowledge, as ‘outsiders' did not always see the differences. Moreover, the street art discourse was much more flexible in its 'style', and as both Laura and Ines point out that rather in naming oneself into one style, the aim was to do an 'own' underived style, distinctive to others in the scene. In opposition to street art, graffiti was both by street artists and graffiti writers more strictly defined: it was simply based on writing your tag name. The women identified as 'graffiti writers' were writing typical signature graffiti: 'tags', 'throw-ups' or painted 'pieces' based on stylistic letters. Moreover, all graffiti writers were more explicit in that their style was graffiti, compared to the street artists who were more flexible in their self-definition. Especially, graffiti writers would pinpoint that they were not interested in street art, but graffiti:

'I'm not into street art, because I don't think it, or my perception of graffiti is that it's based on letters. And characters also, they're also something else. So I think graffiti is letters and in certain spaces and characters is that street arty thing, which I think is different and that I'm not interested in.” - Leena, 28 (graffiti writer)

In short, as the street artists, graffiti writers ensured that street art was defined as something diffuse: 'something else', 'different' and 'not like’ graffiti. Thus, street art was described as something different from the norm (graffiti) and became an object of 'othering'. Graffiti was even clarified as

\footnotetext{
${ }^{4}$ Interviews done in Finnish and translated into English.
} 
something 'pure’ in opposite to street art: ‘...she wasn’t painting pure graffiti either, but did all kinds of weird street art shit.' (Tiina, 25). Tiina was one of the women that I met on legal walls in Helsinki. While at the legal walls, she was usually painting traditionally graffiti pieces and I was impressed about her creative ideas on the letters' structures. When I asked her to participate in the research, I was surprised when she replied: 'Sure but I don't know much about graffiti, but a lot about street art.'. I found out that Tiina was an expierenced street artist and had a lot to say about the inequalitites between the two art scenes. As the intention was to find out how women negotiate their subjectivity in male dominated subcultures, she pointed out a distinct sense in my own way of talking from a graffiti perspective:

Well, if you're talking about how women and men, or like how women feel they are in graffiti circles, but then it's another thing how street artists feel they are with graffiti writers. They're in some way really inferior, I've noticed. It's like, well if you're putting up some stickers, then it's like not real claim of the public space, but something like... Or even if you do big posters, that also feel like graffiti writers are not appreciating it, like when you're doing it with aerosol. So at some point I felt it was a bit weird, it felt like there was some beef between these groups.

As this interview data marks the distinctions between street art and graffiti, it also raises the importance for researchers to detect a subcultural sensibility that recognises the varying subjects within a context that positions them differently in subcultures structures. Moreover, the (re)production of the dominant knowledge paradigms placed graffiti in center, subverting street art. Thus, the picturing of women among street art and graffiti as a relatively unified movement in Helsinki became difficult, as the women negotiated their subjectivity from different locations often based on the structures between street art/graffiti, but also between licit/illicit and invisible/visible.

\footnotetext{
It's ok to do street art, but graffiti...
} 
Several accounts among the interviewees displayed distinctions between street art as 'less harmful' (licit) and graffiti as more 'criminal' (illicit), something that is confirmed by many street art and graffiti studies (Ross 2016). Street art was understood as less serious crime because of the assumptions of being less risky and easily removable, even though some of the street artists revealed multiple techniques of how to maintain your art piece on the surface as long as possible, something that the graffiti writers rarely discussed. Also, the 'street artists' were more likely to be understood as part of the 'legal' scenes of Helsinki, because they were more active in the authorised female-only workshops. Yet, the female-only workshops enabled a 'safe space' for the women to paint, without receiving physical or verbal abuse from the males in the scene, something that was accounted by many of the women participating in the research. Many of the interviewees explained that these workshops functioned as a meeting place for likeminded and a space where 'you can do your thing' without being sexually objectified by males in the subculture. These spaces can be understood as feminist means to resist the sexism women faced in the subcultural groupings. However, the authorised youth projects or self-organised legal projects were not perceived as authentic enough among the more subcultural graffiti writers. Especially, the more illicitly oriented women disclaimed the 'accountability' of such 'girls' and expressed a distaste towards the contemporary politics that tends to popularise graffiti and street art, pointing to a nostalgic notion of the zero tolerance past:

It has just been turned into this trendy thing and I think it's ridiculous. The scene did graffiti before exactly because it wasn't [legal], and because it was something that you're not allowed to do. Maybe this [legalisation] will bring some more chicks into the culture. - Satu, 30 (graffiti writer)

'Maybe this will bring some more chicks into the culture' was said ironically, accompanied by an explanation that legal painters taught by the youth projects were not 'real' or authentic enough. Similarly, other interviewees noted that women who learn to paint in youth projects have to prove their commitment to the subculture much longer than a painter who was self-taught. 'They just 
don’t really know what's really up’, said Katri, noting that subcultural knowledge is only gained through 'real' practice. This lack of solidarity among women in male dominated subcultures has been acknowledged by many previous subcultural studies and is considered an effect of fear of exclusion or being sexualised by the peer group (Leblanc 2006, Lumsden 2010). This 'emphasized femininity' supports the male hegemony of the subculture that re-internalises the gender norms in subculture (Connell 1987, Leblanc 2005, 32), and moreover problematises the understandings of feminist alternative spaces, here the female-only workshops, as being immune to oppressive discourses (Kempson 2016).

The attributes of graffiti, taking risks and being 'criminal', have typically been constructed as masculine (Macdonald 2016, Monto, Machale and Anderson 2012). Failure to perform these standards consequently labelled street art doings as feminine, as street art did not cause big removal costs and it was possible to prepare in private domains, thus it was interpreted as something for 'pussies' by one of the street artists. Even the street art presents a certain rebellion against the orthodox rules of graffiti and breaks down its conventions; it is effectively silenced through the discourses of being less risky. During the field research it became evident that these understandings were much depended on the formations of the dominant discourses and encounters with 'outsiders'. Tiina explains that she never had any troubles with authorities during illicit street art actions:

No, not really, I've been pretty lucky. Some disputes from random by passers, but nothing special. Usually they're just commenting positively or something like that, even I've been in the middle of the night doing some bigger posters in downtown, and well sometimes the dogwalkers see me doing... Then when they really see what I'm doing, they leave me in peace, they'll just stare and wonder for a while but never calls the police or something like that, which is a bit peculiar.

What makes Tiina's account interesting is that she actually did street art in a highly visible and public place, claiming a space in city center, but her doings was permitted by the audience. This illustrates how street art may be defined culturally 'licit' even if placed in public space without 
permission, as citizens do not report or request it. Therefore, the sense of risk is concerned by how likely one will get caught and on which basis (Chackal 2016, 362). In opposite to Tiina, Emmi (graffiti writer) describes how she was caught by plain-clothed guards with a friend in an old train tunnel that was abandon and no longer in public use, but popularly used by graffiti writers. The 'operation' by the plain-clothed guards was militaristically organised as 'four men against two girls' trapped both ends of the tunnel. The guards had been lurking in the middle of the tunnel for graffiti writers before Emmi and her friend even started to paint. After half an hour, the guards surrounded them in the tunnel and called the police to arrest them for vandalism. One of the guards was a 'wellknown’ guard within the graffiti scene in Helsinki:

Yeah, he was really pissed off. And then there were some fairly young [guards] really in a good mood like 'hey [tag name]! I have written a criminal report on you!' And then what else, oh yeah, then they were joking around about we should start to do some guerrilla knitting. They said they wanted to order jumpers from us, like FPS jumpers, where it says 'Fuck FPS' on the back... [...] Yeah, they told us that they had never caught chicks without their lads before.

FPS stands for 'Finnish Protection Service', a former security company that specialised in graffiti prevention. The company does not exist anymore, but the initials are extensively used by both graffiti writers and security guards themselves to signify a specialised graffiti task force. Messerschmidt's (1993) study of crime and masculinities provides a theory of where police work constructs masculinity in a game on behalf of another. Likewise, Macdonald $(2002,119)$ notes the relationship between male graffiti writers and the 'vandal squad' 5 as distinctive, differing from their relation to other 'outsiders' of the subculture. In this distinctive relationship, authorities like the police and security guards see their combat with graffiti writers as a ritualised game and an enjoyable challenge in the struggle for control (Macdonald 2002, 119). Although there is a struggle for control of space such as a train yard or a street, according to Macdonald (2002, 119-121, 124),

\footnotetext{
5 'Vandal squad', originally a unit of New York City Transit Police Department, is often used in the 'graffiti world' as a term to refer to authoritative graffiti task forces.
} 
the relationship is based on a certain mutual respect among the players of the game, where 'the best man may win' in this battle of masculinities. The question here is whether a woman's body may participate respectfully in this battle of masculinities, and moreover with different styles, such as street art. In the context of a subculture avoiding control but also intrigued by the faced risks, the painting body aims to stay invisible, and is then often assumed as 'male'. When these hidden bodies become visible and break the normative assumptions of male bodies, they are femininised in order to fall in line with gender binary. As gender is understood socially constructed, it is done so through performativity (Butler 1990; Halberstam 1998). While Jack Halberstam (1998) demonstrates a more nuanced understanding of gender categories, it is only when these hidden 'female masculinities' are caught in their action and in a certain style, that they become visible and recognised as part of the subcultural battle.

\section{Avoiding the fame game}

Scholars point out that respect, fame and recognition in the subculture, 'claiming a name' on the streets, are the most prominent reasons for painting graffiti and the resources for constructing an identity in the subculture (Ferrell 1996; Macdonald 2002; Snyder 2009). The assumed performative game of the fame and the subsequent fabrication of a matching subcultural career and achieving the status of 'king' (Campos 2012) marginalises different subcultural performativities, were subjects oppose dominant understandings. The subcultural visibility was downplayed by the women, because it was often understood through a 'male' gaze. The relationship to fame for the both graffiti writing and street artist women in Helsinki was somewhat contradictory, as it did not reflect explicitly their motivations or values of the subculture. Only two of the graffiti writing women confessed that fame would be one reason among others for them to paint, rest of the both street 
artists and graffiti writers stating that it 'was not a thing for them'. Moreover, in the case of street art it is even more complicated, as the 'signature' is not the focus of street art doings and therefore gaining a 'name' on streets is depended on the recognition of a certain characteristics or style.

Yes, I think it's because of this fame thing, that boys have accepted the idea of graffiti, the fame and getting name recognition so they'll put more effort on that. But for girls, that fame is not so meaningful and that's why they can release themselves from all that inbready graffiti thing and they'll just really wanna do that for themselves. I dunno, I think this is why I'm not into letters. - Minna, 29 years old (street artist)

I don't have that kind of a personal relationship with fame. Of course, you can't deny that if you're writing graffiti, of course you want somebody to see that. But it's not why I'm doing it, it's more about the experience with the people I hung out with and that dimension where I can live every day without the need to be adjusted into the society that don't represent me. So, I don't need to advertise myself, that's more like distressing. - Leena, 28 years old (graffiti writer)

As the attempt to gain fame seems to be set as a subcultural norm from a male perspective, these women refused to be part of the 'fame game'. Fame becomes hard to define as politics of a personal matter, when it is firstly evaluated through the structures of gender. Instead, these women present meanings that can be situated in individualism and self-hood where they do art because of themselves, and not because of being recognised by the structures of the subcultures.

Emmi was one of the two graffiti writers that admitted that fame did have a meaning for her. I became to know Emmi through the female-only youth workshop, were she was one of the few girls who would be interested in doing graffiti among the street art -oriented group. Her pieces and tags were not only seen on legal walls, but along the railway lines, thus she was performing and living up to somewhat conventional graffiti writers' subcultural standards, claiming a name in the city space. Although she was generally seen as a positive exception in the street art -oriented group, I was asked by my boss to urge Emmi to use another name during the workshops, as it was improper to use the 'illegal' tag name in a municipal led youth work. Thus, she was pretty 'known'. When asking about fame, Emmi admits it is desirable, but explains that she does not want to earn it through the lens of gender: 
Maybe, but then again... sometimes I wanna change my tag name, because everyone knows me already. (...) That's why I think it would be good to have it in secret, so that nobody would know who does what. It would only be the tag name that people know, that would be much cooler. That kind of fame I would like to have, but not like 'that chick does that'.

Macdonald (2002, 137) writes that it can be easy for a woman to become well-known because of her gender is an exception in the subculture. While this might at first look like an advantage, it means that women are sometimes seen as gaining 'easy fame' and as a result fame becomes less meaningful. Pabón $(2016,81)$ notes that choosing 'gender anonymity’ by using a gender neutral/androgynous tag name allows graffiti writers and street artists communicate a message and exercise their artistry without the stigma associated with their gender in everyday life. Subsequently, according to Pabón the decision regarding gender visibility or invisibility affects graffiti writing women more than street artists because the tag name is a central component of the work for the former, which may construct street art as more ‘female friendly’ (Pabón 2016, 81). Macdonald (2016, 235) writes, that less emphasis on fame and name recognition amongst often unnamed street artists may widen the creative boundaries and opportunities to perform and explore femininities in the subculture. Signature graffiti is essentially an affirmation of self within a network of initiates, when street art, generally communicates a variety of ideas (Waclawek 2011, 123). The consequence of avoiding fame through a gender lens and emphasizing gender anonymity was however, that the tagging body was read as 'males' within the subculture:

Satu: I think that if people would know what the chicks are really doing, they would be respected much more, because there are a lot of more hardcore girls than the average guys are. But I think chicks just don’t make a noise of themselves.

M: They don't make much noise of themselves?

S: No. They don't need to be like that, they're not raising that fame, it's not like they're goal in a same way.

When the fame as a collective response for why to do graffiti and street art has been pointed out by scholars, it has been done so through a perspective of masculine values. These women emphasised more individual responses, placing themselves outside the fame discourse. Moreover, as street 
artists proposed a total refusal of the fame game, graffiti writers' critisised the gender based judgements of the fame. Thus, there is a need for researchers to, as Kempson $(2016,148)$ writes, be wary of flattening internal hierarchies within the subcultural spaces by presuming that the participants all share same values, and further that all have equal access to the resources that constitute the normative subject within a subculture.

\section{Conclusion}

The diversity of women seems to be neglected within the graffiti and street art studies, often scattered in to the "girlfriend" or the passive "look out” role (Macdonald 2001). The women I followed in Helsinki shows that women perform various and diverse styles within these overlapping subcultural groupings, making them hard to present as one united group. The women typically positioned themselves in relation to the somewhat opposite discourses of graffiti and street art, but even inside these there where multiple performing's of subcultural identities.

Street art should not be understood as essentially a 'female version’ of graffiti, rather it provides opportunities to reclaim the multi-gendered spaces of the streets through different styles than graffiti. Because street art is presented as the gentle, non-threatening alternative to graffiti, both by dominant and subcultural discourses, it functions as a space where women and/or marginal subjects are easily identified and recognised in street subcultures, where they cultivate a distinct and isolate feminist subculture with a distance from the 'masculine' graffiti subculture. While street art may not present a revolutionary change in graffiti's gender regimes, street artists do present a shift in the dominant paradigms of cultural productions in urban spaces, that is not only directed and dedicated to the graffiti’s 'outlaw masculinity’(Monto, Machalek and Anderson 2012). As the graffiti subculture's masculinist standards make it very difficult for women to be fully recognised, 
street art has somewhat offered a space for the neoliberal projects of feminist 'selves' (see Gonick 2006) in these spheres. The designation 'street art' may represent the 'girl power' -movement or a form of 'riot grrls' within male dominated street subcultures, yet as a 'less' harmful feminism for graffiti as it is in subcultural settings rarely recognized as part of graffiti and therefore not threatening its granted masculine ideals.

Graffiti subculture equips writers with structure and collegial encouragement, but also offers roles that foster discipline and models of behavior (Waclawek 2011, 55). Especially, the hierarchical relationship between 'kings' (and 'queens'), the more established and experienced, and 'toys', the novice and less competent graffiti writer is well documented in many graffiti studies, but this structure remains unexplored among and between women, and in particularly in street art studies. Instead, there seems to be a structure between graffiti and street art, placing the former as superior over the latter in terms of subcultural accountability. Moreover, the tendency to see street art as more legal and less harmful ways of communicate within city space, makes it conventionally more ‘proper’ for women, re-establishing the traditional attributes of femininity. Graffiti remains as the masculinist identity project, in which only rare women are part of, and if so, often violently sexually controlled by her male peers (Macdonald 2002). Further, because of street arts' lucrative markets for art museums and selling works, it is more than welcomed for the middle class values of ‘urban creativity’ and metropolitan agencies (Merrill 2015).

This study demonstrates how women in street art and graffiti shape different identities, based on different distinctive understandings of ideals, practices and motivations in the two subcultural settings. It is therefore not adequate to study women in street art and graffiti as one united group, as they negotiate their structural positions and subvert and negotiate gender regimes through different strategies, and from different locations. The feminist analysis in studies of street art and graffiti are thus obligated to lean on epistemologies that recognizes the structural 
inequalities between subcultures themselves, displaying an intersectional understanding of marginal positions in street subcultures.

\section{References}

Austin, J. 2001. Taking the Train: How graffiti art became an urban crisis in New York City. Columbia University Press.

Fransberg, M. 2013. Graffitikunskap - En etnografisk studie om graffitimålare i en nolltoleransmiljö (Graffiti knowledge - An ethnographicstudie of graffiti writers in zero tolerance milieu). Master thesis, Faculty of Social Sciences, University of Helsinki.

Fransberg, M, 2014. ”Graffititieto - Etnografinen tutkimus graffitimaalareiden alakulttuurista (Graffiti knowledge - Ethnographic Research on Graffiti Writers Subculture)”. Oikeus 2014 (3): 291-313.

Butler, J. 1990. Gender Trouble: Feminism and the subversion of identity. London: Routledge.

Campos, R. 2012. ‘Graffiti writer as superhero’. European Journal of Cultural Studies 16 (2): 155 170.

Castleman, C. 1982. Getting up: Subway Graffiti in New York. Cambridge: MIT Press.

Chackal, T. 2016. 'Of Materiality and Meaning: The Illegality Condition in Street Art'. The Journal of Aesthetics and Art Criticism 74(4): 359 - 370.

Chalfant, H. and Prigoff, J. 1987. Spraycan Art. London: Thames \& Hudson.

Connell, R.W. 1987. Gender and Power: Society, the Person and Sexual Politics. Cambridge: Polity Press.

Ferrell, J. 1996. Crimes of Style: Urban Graffiti and the Politics of Criminality. Boston: Northeastern University Press.

Ferrell, J. and Hamm, M. eds. 1998. Ethnography at the Edge: Crime, Deviance and Field Research. Boston: Northeastern University Press. 
Gailey, J. 2009. Starving is the most fun a girl can have: The pro-ana subculture as Edgework. Critical Criminology 17 (2): 93 - 108.

Ganz, N. ed. 2006. Graffiti Woman. London: Thames \& Hudson.

Gonick, M. 2006. 'Between “Girl Power” and "Reviving Ophelia”: Constituting the Neoliberal Girl Subject’. NWSA Journal 18 (2): 1 - 23.

Halberstam, J. 1998. Female Masculinity. Duke University Press.

Hannerz, E. 2017. 'Bodies, doings, and gendered ideals in Swedish graffiti'. Sociologisk Forskning 54 (4): $373-376$.

Helin, M. 2014. Luvallinen graffiti Helsingissä. 'Meidän kulttuuria ja meidän juttu, kun pääsee tekee...' [Legal graffiti in Helsinki. “Our culture and our thing, when we get to do...”]. Helsinki: Helsingin kaupungin tilastokeskus.

Hodkinson, P. 2005. 'Insider Research’ in the Study of Youth Cultures'. Journal of Youth Studies 8 (2): $131-149$.

Høigård, C. 2007. Gategallerier [Street galleries]. Oslo: Pax forlag.

Isomursu, A. and Jääskeläinen, T. 1998. Helsinki graffiti. Helsinki: Kustantaja Matti Pyykkö.

Kempson, M. 2016. 'Feminism, subculture and the production of knowledge: Developing intersectional epistemologies amidst the reflexive turn' in The Subcultural Imagination: Theory, research and reflexivity in contemporary youth cultures, edited by Shane Blackman and Michelle Kempson, 139-151. New York: Routledge.

Kimwall, J. 2014. The G-word: Virtuosity and Violation, Negotiating and Transforming Graffiti. Årsta: Dokument Press.

Koskela, H. 2009. Pelkokierre: Pelon politiikka, turvamarkkinat ja kamppailu kaupunkitilasta [The spiral of fear. Politics of fear, the security business and the struggle for city space]. Helsinki:

Gaudeamus.

Lachmann, R. 1988. 'Graffiti as Career and Ideology’. American Journal of Sociology 94(2): 229_ 250.

Leblanc, L. 2005. Pretty in Punk: Girl's Gender Resistance in a Boy's Subculture. London: Rutgers University Press. 
Leslie, D. and Hunt, M. 2013. 'Securing the Neoliberal City: Discourses of Creativity and Priority Neighborhoods in Toronto, Canada’. Urban Geography 34 (8): 1171 - 1192.

Lois, J. 2003. Heroic Efforts. New York: University Press.

Lombard, K.-J. 2013. 'Men against the wall: Graffiti(ed) Masculinities'. The Journal of Men's Studies 21: 178-190.

Lumsden, K. 2010. ‘Gendered Performances in a Male-Dominated Subculture: “Girl Racers”, Car Modification and the Quest for Masculinity’. Sociological Research Online 15(3).

Lyng, S. (1990). 'Edgework: A Social Psychological Analysis of Voluntary Risk Taking', American Journal of Sociology, 95(4): 851-886.

Lähteenmaa, J. 1991. Hip-hoppareita, lähiöläisiä ja muita kultturelleja: Nuorisoryhmistä 80- luvun lopulla Helsingissä [Hip-hoppers', hoodies and other culturalities: Youth-groups in Helsinki at the end of 80’s]. Helsingin kaupunki: Nuorisoasiainkeskus.

Macdonald, N. 2002. The Graffiti Subculture: Youth, Masculinity and Identity in London and New York. New York: Palgrave Macmillan.

Macdonald, N. 2016. "Something for boys? Exploring the gender dynamics of the graffiti subculture" in

Madison, S. 2005. Critical Ethnography: Method, Ethics and Performance. London: Sage Publications.

Malinen, P. 2011. Kannu vie - kohti taidetta? Graffitikokemus sekä graffitin ja kuvataideopetuksen vuorovaikutus [The spray can leads you - to art? The graffiti experience and the interaction between graffiti and visual arts education]. Rovaniemi: Lapland University Press.

McAuliffe, C. 2012. 'Graffiti or Street Art? Negotiating the Moral Geographies of the Creative City’. Journal of Urban Affairs 34(2): 199-206.

McRobbie, A. 2009. The Aftermath of Feminism: Gender, Culture and Social Change. London: Sage Publications.

Merrill, S. 2015. 'Keeping it real? Subcultural graffiti, street art, heritage and authenticity’. International Journal of Heritage Studies 21(4): 369 - 389. 
Messerschmidt, J. 1993. Masculinities and Crime. Critique and Reconceptualization of Theory. Lanham, MD: Rowman \& Littlefield.

Monto, M., Machalek, J. and Anderson, T. 2012. 'Boys Doing Art: The Construction of Outlaw Masculinity in a Portland, Oregon Graffiti Crew’. Journal of Contemporary Ethnography 42 (3): $259-290$.

Newmahr, S. 2011. 'Chaos, Order, and Collaboration. Toward a Feminist Conceptualization of Edgework’. Journal of Contemporary Ethnography, 40(6): 682-712.

Pabón, J. 2013. ‘Be About It: Graffiteras Performing Feminist Community’. The Drama Review 57(3): 88-116.

Pabón, J. 2016. 'Ways of being seen: Gender and the writing on the wall' in Routledge Handbook of Graffiti and Street Art edited by Jeffrey Ross, 78-91. New York and London: Routledge.

Ross, J. 2016. 'Sorting it all out' in Routledge Handbook of Graffiti and Street Art, edited by Jeffrey Ross, 1 - 10. New York and London: Routledge.

Ross, J., Bengtsen, P., Lennon, J., Phillips, S. and Wilson, J. 2017. 'In search of academic legitimacy: The current state of scholarship on graffiti and street art'. The Social Science Journal 54: $411-419$.

Snyder, G. 2009. Graffiti lives! Beyond the Tag in New York's Urban Underground. New York: University Press.

Tolonen, T. 2013. 'Youth Cultures, Lifestyles and Social Class in Finnish Contexts'. Young: Nordic Journal of Youth Research 21(1): 55-75.

Waclawek, A. 2011. Graffiti and Street Art. London: Thames \& Hudson Ltd. 